\title{
O Direito à Cidade
}

\author{
Right to THE City
}

LEFEBVRE, Henri. O direito à cidade. Tradução: Rubens Eduardo Frias. São Paulo: Centauro, 2001.

\section{Jussara Romero Sanches ${ }^{1}$}

Como citar: SANCHES, Jussara Romero. O direito à cidade. Revista do Direito Público, Londrina, v. 12, n. 1, p.318-321, abr. 2017. DOI: 10.5433/24122-107817-1X.2017v17n1p318. ISSN: 1980-511X.

O livro intitulado Direito à Cidade, do filósofo e sociólogo Henri Lefebvre, se propõe a discutir a construção social do espaço urbano, a partir da percepção de que o desenvolvimento urbano pode se estruturar de forma diferente da que se estabelece nas sociedades capitalistas. O próprio autor destaca a intensidade do texto e afirma que está se dá em função do objetivo do livro de propiciar uma abertura de pensamento e ação na direção de novos horizontes e caminhos.

Apesar de ser uma obra enxuta o livro aborda de forma crítica e densa a discussão sobre a construção do espaço urbano nas sociedades capitalistas. O livro é dividido em 15 capítulos, excetuando a apresentação e um capítulo que o autor intitula de advertência. O contexto social no qual o texto foi escrito tem como pano de fundo as transformações sociais e urbanísticas pelas quais Paris passou ao longo da década de 1960.

1 Mestranda no Programa de Direito Negocial da Universidade Estadual de Londrina. Especialista em Direito do Estado e Graduada em Ciências Sociais e em Direito pela Universidade Estadual de Londrina. E-mail: jussararomerosanches@gmail.com 
O primeiro capítulo, "Industrialização e urbanização: noções preliminares", aponta que a industrialização e a urbanização são as principais características da sociedade moderna e devem ser o ponto de partida para sua análise. O autor perpassa as transformações urbanísticas pelas quais passaram diversas cidades. Destaca-se que neste capítulo o autor define o seu entendimento por vida urbana, que possui como pressuposto os encontros, os confrontos entre as diferenças, incluindo as ideológicas e políticas, dos diferentes modos viver que coexistem na cidade.

Para o autor a cidade possuía um atributo específico, o local do habitat, ou seja, era o local no qual se participava de uma vida social, de uma comunidade, tanto nas aldeias, como nas cidades. No entanto, na estrutura da sociedade capitalista e com consolidação do consumo como elemento central dessa sociedade, essa noção de habitat se perde, a cidade é suburbanizada e o proletariado é afastado da cidade, perdendo "o sentido da obra", esfumaçando em sua consciência sua capacidade criadora.

Destaca-se a crítica feita pelo autor em relação à mercantilização do espaço urbano. Aponta que na construção do espaço urbano capitalista há um conflito expresso entre o valor de troca e o valor de uso da cidade, ou seja, a dimensão mercantil, de espaços urbanos comprados e vendidos, de consumo de bens e de lugares, com a dimensão de vida urbana na cidade e com o tempo urbano.

Esse conflito, inerente às próprias contradições da sociedade capitalista, aparece na análise feita pelo autor na construção espaço urbano, uma vez que este compreende a cidade como um produto histórico das relações dos homens, logo ligado a forma capitalista com a qual a sociedade moderna se organiza. A cidade é uma produção e 
reprodução de seres humanos e por seres humanos. Possui, portanto, uma história, sendo obra de grupos de pessoas e homens determinados que realizam a cidade em condições históricas determinadas.

Como produto histórico das relações sociais, o autor destaca dois papéis históricos da cidade, o de acelerador de processos, tanto relativos ao mercado e às trocas, como em relação à acumulação de capitais e conhecimentos e em relação a concentração desses capitais, e o de local das revoluções. A cidade moderna, para o autor, é o local de intensificação, de organização da exploração de toda a sociedade, e aqui destaca-se que a exploração não se restringe à classe trabalhadora, mas de todas as outras classes sociais não dominantes.

No capítulo "O direito à cidade", o autor inicia colocando em oposição as necessidades inerentes à sociedade urbana. Aponta para as necessidades individuais, marcadas pelo consumo, mas destaca outras necessidades que possuem fundamentos antropológicos, opostas e complementares entre si como, por exemplo, a necessidade de unidade e de diferença. Ao abordar as necessidades urbanas, o autor se pergunta se essas necessidades apenas não se realizariam em um lugar no qual as trocas não fossem comandas pelo valor de troca, pelo comércio e pelo lucro.

Tendo em vista que é impossível a reconstituição da cidade antiga que possuía o sentido de habitat, para o autor, apenas seria possível a construção de uma nova cidade, desde que sob novas bases, em outra escala, em outras condições, em uma outra sociedade, superando, portanto, a forma capitalista de organização social. O direito à cidade está ligado, não a um direito de visita ou de retorno às cidades tradicionais, está ligado, para o autor, ao direito à vida urbana, transformada, renovada.

$\mathrm{O}$ direito à cidade se concretiza em uma sociedade organizada 
em outras bases, que não capitalista. É colocado pelo autor como forma superior dos direitos, que congrega em si o direito à liberdade, à individualização na socialização, o direito ao habitat e ao habitar, o direito a participar da construção da cidade, bem como o direito de apropriação do produto construído, que o autor afirma ser bem diferente do direito de propriedade.

Sintetizando o quer dizer o direito à cidade, no capítulo final, "Teses sobre a cidade, o urbano e o urbanismo", o autor pontua que o direito à cidade é o direito à vida urbana, e a tudo que ela pode representar enquanto local de encontros e de trocas, ao passo que a vida e os empregos permitam o uso pleno e completo desses momentos e locais.

Reafirmando sua influência marxista, o autor sentencia que a concretização do direito à cidade, inserida nas perspectivas revolucionárias hegemonicamente operárias, se dá pela proclamação e pela realização da vida urbana como reino do uso, ou seja, da troca e do encontro separados da esfera do mercado, exigindo para sua concretização o domínio do econômico, que se materializa no valor de troca, no mercado e na mercadoria.

Como citar: SANCHES, Jussara Romero. O direito à cidade. Revista do Direito Público, Londrina, v. 12, n. 1, p.318-321, abr. 2017. DOI: 10.5433/24122-107817-1X.2017v17n1p318. ISSN: 1980-511X.

Recebida em: 18/03/2017

Aprovada em:20/03/2017 